\section{Separation and Identification of 20 Pesticides in Their Mixture ${ }^{\dagger}$}

\author{
Keisuke Suzuki, Koichi Miyashita, \\ Hidemitsu Nagayoshi and \\ Tsukasa KasHIwA
}

Agricultural Chemicals Inspection Station, Ministry of Agriculture and Forestry, Kodaira-shi, Tokyo

Received September 22, 1972

The systematic separation and determination of each pesticide from mixtures of many kinds of pesticides is very applicable to the determination of these residues in crops, phytotoxic ingredients in technical products and toxicological ingredients in mammalia. Although numerous analytical methods have been established for pesticides, most of them deal with a sole kind of pesticides.

Sans $^{11}$ reported a multiple residue method for pesticides using column chromatography and gas chromatography, but not systematically.

The systematic separation and identification of various kinds of pesticides have been reported ${ }^{2-3}$ in the field of medicolegal chemistry. However, the reports are merely related to qualitative analyses among the same groups as organophosphorus, organochlorine or organomercuric pesticides.

This paper reports a preliminary trial to establish the systematic identification and determination of many kinds of pesticides by column, thin-layer and gas chromatography and presents the separateion of 20 pesticides into some divisions in which pesticides were roughly identified and determined.

The procedure was as follows: A glass-wool plug was placed in the bottom of a chromatographic tube $(2.0 \times 30 \mathrm{~cm})$ to support the column. Five grams of silica gel (Mallinckrodt Chemical Works) were added to the tube and sucked from the bottom under reduced pressure of $100 \mathrm{mmHg}$. A mixture of 20 pesticides, $20 \mathrm{mg}$ in total, was mixed throughly with $0.5 \mathrm{~g}$ of dry silica gel and transferred quantitatively to the tube, and a glass-wool plug was pressed down firmly on the surface of the sample with the aid of a glass-rod. The column was developed at the rate of $1 \mathrm{ml}$ per minute by addition of solvent systems shown in Table I. The solvents were added to the top of the chromatographic column through a reservoir which permitted the application of gas pressure from a nitrogen tank.

+ Studies on the Systematic Identification and Determination of Pesticides. Part III. See Reference 4).
Table 1. Separation of 20 Pesticides ${ }^{a !}$ into Five Divisions by Column Chromatography ${ }^{b}$ ) Using a Stepwide Method

\begin{tabular}{|c|c|c|}
\hline $\begin{array}{l}\text { Division } \\
\text { No. }\end{array}$ & Solvent systems & $\begin{array}{l}\text { Volume of } \\
\text { solvent (ml) }\end{array}$ \\
\hline I & Hexane-benzene $(8: 2)$ & 80 \\
\hline II & Hexane-benzene $(1: 1)$ & 45 \\
\hline III & Hexane-benzene $(3: 7)$ & 75 \\
\hline IV & $\begin{array}{l}\text { Hexane-ethylacetate- } \\
\text { acetone }(8: 1.5: 0.5)\end{array}$ & 70 \\
\hline V & Acetone & 80 \\
\hline \multicolumn{3}{|c|}{$\begin{array}{l}\text { A mixture of } 20 \text { pesticides, } 20 \mathrm{mg} \text { in total, was } \\
\text { mixed throughly with } 0.5 \mathrm{~g} \text { of silica gel and added } \\
\text { to the column. } \\
\phi 2.0 \times 30.0 \mathrm{~cm} \text {, packed with } 5 \mathrm{~g} \text { of silica gel ( } 100 \\
\text { mesh). }\end{array}$} \\
\hline
\end{tabular}

Twenty pesticides were separated into five divisions. by this procedure. Moreover, pesticides of each division were developed by two-dimensional thin-layer chromatography (Fig. 1, D. I D.V), and identified by the UV method and $o$-tolidine-UV method described in a previous paper. ${ }^{4}$

Chlorpropham and chlorobenzilate in Division III (D. III) were detected by the methods of Coha et al. ${ }^{5}$, and Kanda et al.,2) respectively. The lower limit of identification in these methods was less than $1 \mu \mathrm{g}$ Pesticides in D. IV were detected by the UV method. Furthermore, the presence of chlorpropham, pentanochlor, swep and propanil were confirmed by the method of Coha et al.,5) while propazine by the pyridine-alkaline method.

The pyridine-alkaline method was as follows: A silica plate was sprayed with a $70 \%(\mathrm{v} / \mathrm{v})$ solution of pyridine and heated at $100^{\circ} \mathrm{C}$ in an oven for $30 \mathrm{~min}$. It was then sprayed with $9 \mathrm{~N} \mathrm{NaOH}$ to give a yellow spot of propazine on the plate. The lower limit of identification of this method was about $3 \mu \mathrm{g}$.

Diuron in $\mathrm{D} . \mathrm{V}$ was also confirmed by the method of Coha et al. ${ }^{5}$ Most of pesticides in each division were further confirmed by gas chromatography. Table II shows the gas chromatographic retention times and approximate recoveries of pesticides in each division. Some pesticides were detected in two adjacent divisions, respectively, but they were recovered in one division more than $65 \%-e . g$., chlorfenson in D. III and chlorthiamid in D. IV. Dichlone was detected in both D. III and D. IV, but the recovery was not more than $30 \%$.

This low recovery of dichlone can be explained from the formation of another compound with chlorpropham during the process of determination. Then, the following experiment was conducted in order to test the hypothesis. Chlorfenson, tetradifon, endrin, chlorpropham and tetrachloroisophthalonitrile were separately added to acetone solutions of dichlone. After standing 

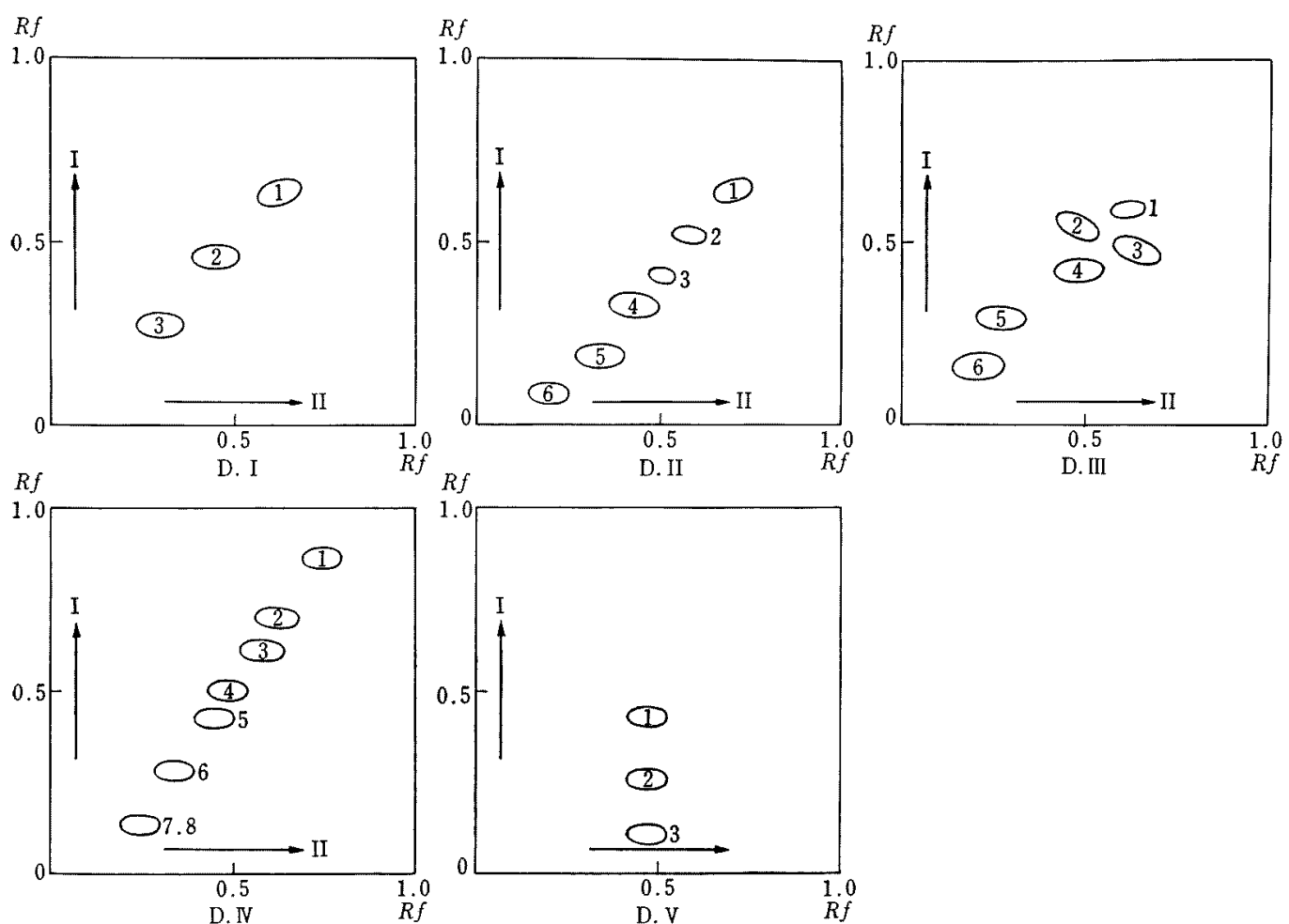

FIG. 1. Separation of Pesticides in Each Division (D.I $\sim$ D.V) by Two-dimensional Thin-layer Chromatography.

Pesticides:

D. I; (1) quintozene; (2) p, p'-DDT; (3) pentachlorophenyl acetate.

D. II; (1) pentachlorophenyl acetate; (2) dichlofenthion; (3) p-nitrophenyl 2,4,6-trichlorophenyl ether; (4) endrin; (5) nitrofen; (6) chlorfenson.

D. III; (1) chlorfenson; (2) tetradifon; (3) tetrachloroisophthalonitrile; (4) dichlone; (5) chlorpropham; (6) chlorobenzilate.

D. IV; (1) dichlone; (2) chlorpropham; (3) chlorobenzilate; (4) pentanochlor; (5) swep; (6) propazine; (7) propanil; (8) chlorthiamid.

D. V; (1) diuron; (2) chlorthiamid; (3) chloramphenicol.

Solvent systems:

D. I; (1) Hexane-benzene (9:1); (II) Hexane.

D. II; (1) Hexane-benzene (9:1), twice; (II) Hexane-benzene $(9: 1)$.

D. III; (1) Hexane-benzene ( $7: 3$ ), twice; (II) Hexane-acetone (9:1).

D. IV; (1) Hexane-acetone $(9: 1)$, once + Hexane-benzene $(7: 3)$, once; (II) Hexane-acetone (9:1), once + Hexane-benzene $(7: 3)$, twice.

D. V; (1) Hexane-acetone $(7: 3)$.

overnight at room temperature, these solutions were applied to a silica plate and developed with a mixture of hexane-benzene ( $7: 3)$, three times. Only the dichlone solution containing chlorpropham gave an orange spot at origin, which can not be identified. When a mixture of dichlone and chlorpropham was examined by thin-layer chromatography soon after they were mixed, no unknown spot appeared on the silica plate.

Since chlorpropham and pentanochlor in D. IV were difficult to be determined directly by gas chromatography, they had to be hydrolyzed, and brominated prior to injection. In order to analyze chlorpropham and pentanochlor, pesticides in D. IV were further chromatographed by thin-layer chromatography using a continuous flow-development method (Fig. 2). Two bands of chlorpropham and pentanochlor on the silica plate were scraped to be eluated, brominated and determined by the method of Gutenmann et al. ${ }^{6}$ )

Chlorobenzilate and dichlone did not interfere with this method. The band of propazine on the silica plate was also scraped to be eluated and determined by a modification of the method developed for dyrene.7) Swep did not interfere with this analytical method.

Diuron in D. V was observed on the gas chromato- 
Table II. Gas Chromatographic ${ }^{a}$ Retention Times and Approximate Recoveries of Pesticides in Each Division

\begin{tabular}{|c|c|c|c|c|c|c|}
\hline \multirow{2}{*}{ Pesticide } & \multirow{2}{*}{$\begin{array}{l}\text { Division } \\
\text { No. }\end{array}$} & \multicolumn{4}{|c|}{ Retention time (min) } & \multirow{2}{*}{$\begin{array}{l}\text { Recoveries } \\
(\%)\end{array}$} \\
\hline & & $\mathrm{A}^{b 1}$ & B & $\mathrm{C}$ & $\mathrm{D}$ & \\
\hline Quintozene & \multirow{4}{*}{ I } & 2.7 & & 2.0 & & 100 \\
\hline \multirow[t]{2}{*}{$p, p^{\prime}-\mathrm{DDT}$} & & 13.3 & & 11.5 & & \multirow[t]{2}{*}{100} \\
\hline & & & & 14.7 & & \\
\hline $\begin{array}{l}\text { Pentachlorophenyl acetate } \\
\text { Pentachlorophenyl acetate }\end{array}$ & & 3.1 & & 2.4 & & 100 \\
\hline $\begin{array}{l}\text { Pentachlorophenyl acetate } \\
\text { Nitrofen }\end{array}$ & \multirow{8}{*}{ II } & 3.1 & & 2.4 & & 5 \\
\hline $\begin{array}{l}\text { Nitrofen } \\
p \text {-Nitrophenyl 2,4,6- }\end{array}$ & & 19.4 & & 9.3 & & 100 \\
\hline $\begin{array}{l}p \text {-Nitrophenyl } 2,4,6- \\
\text { Trichlorophenyl ether }\end{array}$ & & 24.8 & & 12.9 & & 100 \\
\hline $\begin{array}{l}\text { Trichlorophenyl ether } \\
\text { Dichlofenthion }\end{array}$ & & & & & & \\
\hline $\begin{array}{l}\text { Dichlofenthion } \\
\text { Endrin }\end{array}$ & & 3.8 & & 2.8 & & 100 \\
\hline \multirow{2}{*}{ Endrin } & & 24.6 & & 10.6 & & 75 \\
\hline & & & & 16.2 & & \\
\hline Chlorfenson & & 17.4 & & 6.8 & & 26 \\
\hline Dichlofenthion & \multirow{9}{*}{ III } & 3.8 & & 2.8 & & 5 \\
\hline Endrin & & 24.6 & & 10.6 & & 28 \\
\hline & & & & 16.2 & & \\
\hline $\begin{array}{l}\text { Chlorfenson } \\
\text { Tetrachloroiso phthalonitrile }\end{array}$ & & 17.4 & & 6.8 & & 80 \\
\hline $\begin{array}{l}\text { Tetrachloroiso phthalonitrile } \\
\text { Tetradifon }\end{array}$ & & 7.8 & & 2.1 & & 100 \\
\hline $\begin{array}{l}\text { Tetradifon } \\
\text { Dichlone }\end{array}$ & & 57.5 & & 24.7 & & 100 \\
\hline $\begin{array}{l}\text { Dichlone } \\
\text { Chlorpropham }\end{array}$ & & 4.8 & \multirow{3}{*}{4.6} & 2.3 & & 20 \\
\hline $\begin{array}{l}\text { Chlorpropham } \\
\text { Chlorobenzilate }\end{array}$ & & $-c$ & & - & & Trace $^{d !}$ \\
\hline Chlorobenzilate & & 13.4 & & 11.0 & & Trace \\
\hline Dichlone & \multirow{8}{*}{ IV } & 4.8 & \multirow{5}{*}{4.6} & 2.3 & & 10 \\
\hline Chlorpropham & & - & & - & & 66 \\
\hline Chlorobenzilate & & 13.4 & & 11.0 & & 100 \\
\hline Swep & & 3.3 & & 2.1 & & 100 \\
\hline Propanil & & 7.9 & & 4.7 & & 100 \\
\hline Pentanochlor & & - & \multirow[t]{3}{*}{$\begin{array}{l}2.6 \\
4.6\end{array}$} & - & & $98^{d !}$ \\
\hline Propazine & & - & & 1.8 & & $100^{f t}$ \\
\hline Chlorthiamid & & 1.1 & & 0.4 & & 90 \\
\hline Chlorthiamid & \multirow{3}{*}{$\mathrm{V}$} & 1.1 & & 0.4 & & 10 \\
\hline Diuron & & 0.5 & & 0.4 & & $105^{f)}$ \\
\hline Chloramphenicol & & - & & - & 13.5 & $100^{-1}$ \\
\hline
\end{tabular}

a) A Wilkenes M. 680 instrument equipped with an electron capture detector of ${ }^{3} \mathrm{H}$ source contained a 5 -feet $\times 1 / 8$-inches $i . d$. glass column.

b) A: $5 \%$ QF-1 on Gaschrom Q $80 \sim 100$ mesh, column temp. $169^{\circ} \mathrm{C}$, nitrogen flow rate $10 \mathrm{ml} / \mathrm{min}$.

B: The same column as above, column temp. $169^{\circ} \mathrm{C}$, nitrogen flow rate $40 \mathrm{ml} / \mathrm{min}$.

C: $5 \%$ HV Grease on Chromosorb W(AW) $40 \sim 60$ mesh, column temp. $169^{\circ} \mathrm{C}$, nitrogen flow rate $23 \mathrm{ml} / \mathrm{min}$.

D: The same column as above, column temp. $185^{\circ} \mathrm{C}$, nitrogen flow rate $23 \mathrm{ml} / \mathrm{min}$.

c) No peak.

d) The values of brominated derivatives.

e) The value of silylated derivative.

$f$ ) Determined by spectrophotometry. 


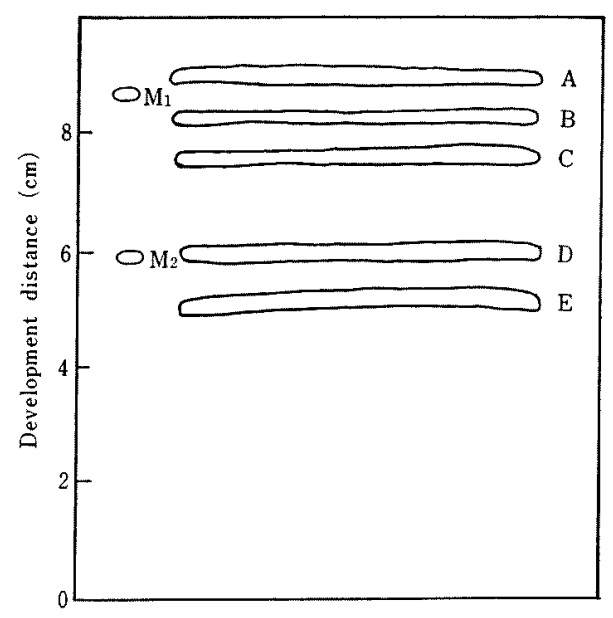

FIG. 2. Separation of Pesticides in D. IV by Thinlayer Chromatography ${ }^{a}$ Using Continuous Flow Development Method.

A. Chlorpropham, chlorobenzilate, dichlone; B. pentanochlor; C. swep, propazine; D. propanil; E. chlorthiamid.

$\mathbf{M}_{1}$. Yellow AB (marker); $\mathrm{M}_{2}$. ACN (3-amino-3chloro-1,4-naphthoquinone)(marker).

a) The cover plate was $9 \mathrm{~cm}$ long from the origin, and the distance between it and the surface of the silica plate was $0.2 \mathrm{~cm}$.

The silica plate was developed with a mixture of hexane-acetone $(9: 1)$ until $A C N$ reached $6.0 \mathrm{~cm}$ from the origin.

grams, but the shape of its peak was too incomplete to be determined. After the eluate of $D$. $V$ from the column was further quantitatively examined by thinlayer chromatography under the condition shown in Fig. 1, the band of diuron on the plate was scraped to be determined by the method of Bleidner et al. ${ }^{8}$

As chloramphenicol was not chromatographed directly, it was silylated by the method described below and injected to a gas chromatograph. The procedure was as follows: One milliter of an acetone solution containing about $20 \mu \mathrm{g}$ of chloramphenicol was placed in a $10 \mathrm{ml}$ ground-glass stoppered test tube and the solvent was evaporated. After $200 \mu \mathrm{l}$ of 25 per cent $(\mathrm{v} / \mathrm{v}) \mathrm{N}, \mathrm{O}$-bis(trimethylsilyl) acetamide in acetonitrile was added to the test tube, the content was warmed in an oil bath at $40^{\circ} \mathrm{C}$ for $5 \mathrm{~min}$. Then, $1 \mathrm{ml}$ of acetonitrile was added into the content and a $3 \mu 1$ of the solution was injected into a gas chromatograph under the condition shown in Table II.

The calibration curve of this method was found to be a linear in the range from 20 to $60 \mathrm{ng}$. From the results of these experiments, 20 pesticides were separated into five divisions, and pesticides in each division were roughly identified and determined.

Acknowledgement. The authors wish to express sincere thanks to Dr. T. Suzuki, the director of the inspection station, for his interest and support on this work.

\section{REFERENCES}

1) W. W. Sans, J. Agr. Food Chem., 15, 192 (1967).

2) M. Kanda, K. Takahama, M. Tsubaki, H. Yoshizaki, C. Watanabe and T. Kiyofuzi, Jap. J. Legal Med., 22, 229 (1968).

3) Y. Doi, ibid., 21, 595 (1967).

4) K. Suzuki, K. Miyashita and T. Kashiwa, Bulletin of the Agricultural Chemicals Inspection Station, 10, 24 (1970).

5) F. Coha and V. Vojinovic, Analyst. Lett., 1, 443 (1968); Anal. Abstr., 17, 1185 (1969).

6) W. H. Gutenmann, D. J. Lisk, $J$. Assoc, Offic. Anal. Chemists, 46, 859 (1963).

7) H. P. Burchfield and E. E. Storrs, Contribs Boyce Thompson Inst., 18, 319 (1956).

8) W. E. Bleidner, H. M. Baker, M. Levilsky and W. K. Lowen, J. Agr. Food Chem., 2, 476 (1954). 